\title{
Morphological abnormalities of rabbit spermatozoa studied by scanning electron microscope and quantified by light microscope
}

\author{
G Kuzminsky ${ }^{1}$, AM Fausto ${ }^{2}$, P Morera ${ }^{1}$ \\ 1 Unconventional Rabbit-Breeding Experimental Centre, Animal Husbandry Institute; \\ 2 Environmental Science Department, Tuscia University, 01100 Viterbo, Italy
}

(Received 11 September 1995; accepted 26 July 1996)

\begin{abstract}
Summary - Rabbit spermatozoa morphological abnormalities were examined to establish criteria for judging the quality of ejaculates. Ten New Zealand White bucks, aged 9 months and weighing $4.3 \pm 0.2 \mathrm{~kg}$, were placed in a climatic chamber for 3 weeks at $+20^{\circ} \mathrm{C}$ and $70 \% \mathrm{RH}$. Sperm was collected three times a week using an artificial vagina. The use of a scanning electron microscope (from $\times 2000$ to $\times 15000$ ) in this study produced an illustrated guide for the classification of abnormalities. Mean percentage quantitative values studied by light microscope $(x 400)$ observation were: $18.2 \%$ total abnormalities, $2.9 \%$ head abnormalities, $13.6 \%$ tail abnormalities and $1.7 \%$ broken spermatozoa. Variability was very high (CV $35.7,54.0,45.3$ and $32.5 \%$, respectively); consequently, each ejaculate should be analysed before use for artificial insemination. Among the different tail abnormalities observed, the most frequent were coiled tails, $9.1 \%$, cytoplasmic droplets, $2.4 \%$, bent tails, $1.3 \%$ and swollen tails, $0.5 \%$.
\end{abstract}

rabbit / spermatozoon / morphology / scanning electron microscopy / artificial insemination

Résumé - Anomalies morphologiques du sperme de lapin étudiées au microscope électronique à balayage et quantifiées en microscopie optique. Les anomalies morphologiques des spermatozoïdes de lapin ont été étudiées pour améliorer les critères de jugement de la qualité des éjaculats. Dix mâles (Néozélandais blancs) à l'áge de neuf mois et 4,3 $\pm 0,2 \mathrm{~kg}$ de poids ont été logés pour trois semaines dans une pièce climatisée à $+20^{\circ} \mathrm{C}$ de température ambiante et $70 \% \mathrm{HR}$. Le sperme a été collecté à l'aide d'un vagin artificiel, trois fois par semaine. Les observations au microscope électronique à balayage (de $\times 2000$ à $\times 15000$ ) ont permis de faire une classification illustrée des anomalies. Les pourcentages ont été estimés au microscope optique $(x 400)$. Les valeurs moyennes sont : $18,2 \%$ d'anomalies totales, dont 2,9\% de têtes anormales, $13,6 \%$ de flagelles anormaux, 1,7\% de spermatozoïdes cassés. La variabilité est très importante (CV 35,7, 54,0, 45,3 et 32,5\% respectivement) et, par conséquent, chaque éjaculat devrait être analysé avant son utilisation en insémination artificielle. Parmi les 
anomalies de flagelles, les plus nombreuses étaient les flagelles enroulés $(9,1 \%)$. Les fréquences de gouttelettes cytoplasmiques et de flagelle angulé et renflé étaient respectivement de $2,4,1,3$ et $0,5 \%$.

lapin / spermatozoïde / morphologie / microscope électronique à balayage / insémination artificielle

\section{INTRODUCTION}

The quantity of morphological abnormalities is sometimes considered, among other factors, in the evaluation of rabbit sperm quality used in artificial insemination (Boussit, 1989; Battaglini, 1992; Castellini, 1993; Facchin et al, 1993).

Normal morphology of rabbit spermatozoa has already been characterized by scanning electron microscope (SEM) analysis (Phillips, 1972; Fléchon and BustosObregon, 1974; Motta and Van Blerkom, 1975); however, there are few studies by SEM on rabbit spermatozoa abnormalities (Dott, 1969; Hafez and Kanagawa, 1973; Bamba and Cran, 1988).

The aim of the present work was to perform an investigation that defined an iconographic typology of abnormal rabbit spermatozoa in order to classify morphological abnormalities. Frequencies in each class were also considered.

\section{MATERIAL AND METHODS}

\section{Animals and experimental conditions}

Ten New Zealand White rabbit bucks, of similar age (9 months) and body weight $(4.3 \pm 0.2 \mathrm{~kg})$, and already trained for 2 months in the sperm collecting technique using an artificial vagina, were placed in a climatic chamber at $20.3 \pm 1.1^{\circ} \mathrm{C}$ (programmed $20^{\circ} \mathrm{C}$ ) as the ambient temperature for a period of 3 weeks. The relative humidity was $69.1 \pm 3.5 \%$ (programmed $70.0 \%$ ) and the lighting consisted of $12 \mathrm{~h}$ a day, from 0800 to 2000 hours (20 lux at cage level).

\section{Sperm collection}

Semen was collected three times a week during 3 weeks and each collection was made, for each male, by two consecutive ejaculations at $15 \mathrm{~min}$ intervals, as is used in commercial breedings specialized in the production of sperm doses for artificial insemination.

\section{Sperm analysis}

Semen analyses were performed on the first ejaculation of the last weekly semen collection to leave a period of time between two consecutive analyses. The samples were divided, a few seconds after collection, into two aliquots to be analysed by phase contrast light microscope (LM; Nikon SE) or by scanning electron microscope (SEM; 5200 Jeol JSM).

\section{Light microscope analysis}

A magnification $(x 400)$ normally adopted by Italian rabbit breeders was used for the LM observations in order to obtain data that would be easily transferable into practice. This magnification also permits the enumeration of the many kinds of morphological abnormalities (Boussit, 1989).

Many Italian breeders currently perform artificial insemination on their own rabbits and appreciate the support of microscopic observations (Battaglini, 1992). To remain within the limits of field practicability, implying that a technique must be rapid, simple and easily performed with the means at hand, the spermatozoa were neither fixed nor stained. The analyses were performed a maximum of $5 \mathrm{~h}$ after the time of the semen collection to avoid possible artefacts.

To perform the quantitative analysis, the fresh sperm were diluted $1: 100$ by a blood diluting pipette in a $3 \% \mathrm{NaCl}$ solution (Bagliacca et al, 
1987) to kill the cells and facilitate counting. A drop of this solution was put in a Bürker chamber and, after 2 min (the required stabilizing time), the analysis was begun. Every week 200 spermatozoa were observed for each of the ten males, for a total of 6000 spermatozoa. To eliminate possible mistakes due to the subjective evaluation of the different abnormalities, the same operator performed all the analyses.

The classification that was developed for cattle and pigs, and that has been used for rabbits by some authors (Bamba and Cran, 1988; Radnai et al, 1988; Barth and Oko, 1989; Boussit, 1989; Della Porta et al, 1991), was used here to divide the spermatozoa into the following categories:

- normal spermatozoa;

- spermatozoa with head abnormalities (acrosome abnormalities and shape and dimension abnormalities);

- spermatozoa with tail abnormalities (bent tails, coiled tails, swollen tails, cytoplasmic droplets);

- broken spermatozoa (1/2 $\sum$ headless + tailless).

\section{Scanning electron microscope analysis}

In preparation for SEM analysis, the spermatozoa, soon after ejaculation, were fixed for $2 \mathrm{~h}$ in $5 \%$ glutaraldehyde and $4 \%$ paraformaldehyde in $0.1 \mathrm{M}$ cacodylate buffer, $\mathrm{pH} 7.2$ (Karnovsky, 1965), dried by the critical point method using liquid $\mathrm{CO}_{2}$ in a Balzers CPD 020 apparatus, attached to specimen holders and coated with gold in a Balzers Union MED 010 evaporator. Magnification used was from $\times 2000$ to $\times 15000$ and the abnormalities observed were illustrated by photographs. A total of about 6000 spermatozoa were observed.

\section{Statistical analyses}

Data obtained by LM were analysed by least square analysis with the following linear model:

$$
y_{i j k}=\mu+\alpha_{i}+\beta_{j}+(\alpha \beta)_{i j}+\varepsilon_{i j k}
$$

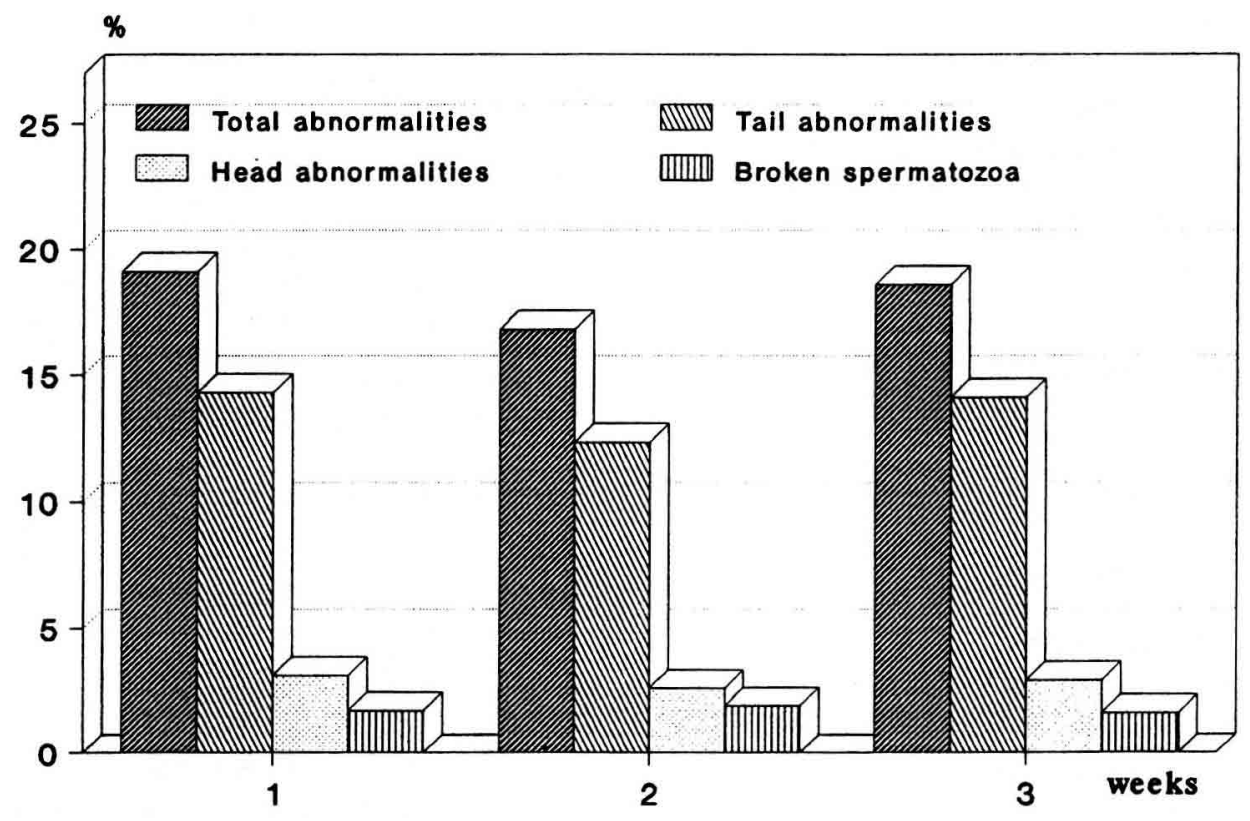

Fig 1. Comparisons between percentages of spermatic abnormalities observed by phase contrast ligh microscope. 
where $y_{i j k}=$ individual variable; $\mu=$ mean effects; $\alpha_{i}=$ th subject effect $(i=1, \ldots 10) ; \beta_{j}=$ th week effect $(j=1, \ldots 3) ;(\alpha \beta)_{i j}=$ interaction between $\alpha$ and $\beta$ effects; and $\varepsilon_{i j k}=$ residual error.

For the figures, the means were expressed as percentages.

\section{RESULTS}

\section{Quantitative analysis by $L M$}

The mean value of abnormalities observed under LM was $18.2 \%$ (CV $35.7 \%$ ). The breakdown into the different categories of abnormalities is given in figure 1. Among the identified categories, head abnormalities and broken spermatozoa represented a low proportion of the total number of spermatozoa viewed: $2.9 \%$ (CV $54.0 \%$ ) for those referring to head and $1.7 \%$ (CV 32.5\%) for those referring to broken spermatozoa. Tail abnormalities represented $13.6 \%$ (CV $45.3 \%$ ) of the observed spermatozoa and $74.7 \%$ of the total abnormalities.

Statistical analysis of the data did not reveal any significant differences between the means of the three collections for each morphological variable considered. There was high variability but the confidence limits were very narrow (from a range of $\pm 0.2 \%$ for swollen tails to a maximum of $\pm 0.9 \%$ for total abnormalities).

The $13.6 \%$ (of total number of spermatozoa viewed) due to tail abnormalities represented $9.1 \%$ (CV $48.6 \%$ ) coiled tails, $2.4 \%$ (CV 69.9\%) cytoplasmic droplets, $1.3 \%$ (CV $60.4 \%$ ) bent tails and $0.5 \%$ (CV 107.4\%) swollen tails (fig 2).

A high correlation between tail and total abnormalities was observed $(r=0.97 ; P<$ 0.001 ). The correlation between coiled tails and tails or total abnormalities was $r=0.91$ $(P<0.001)$ and $r=0.85(P<0.001)$, respectively.

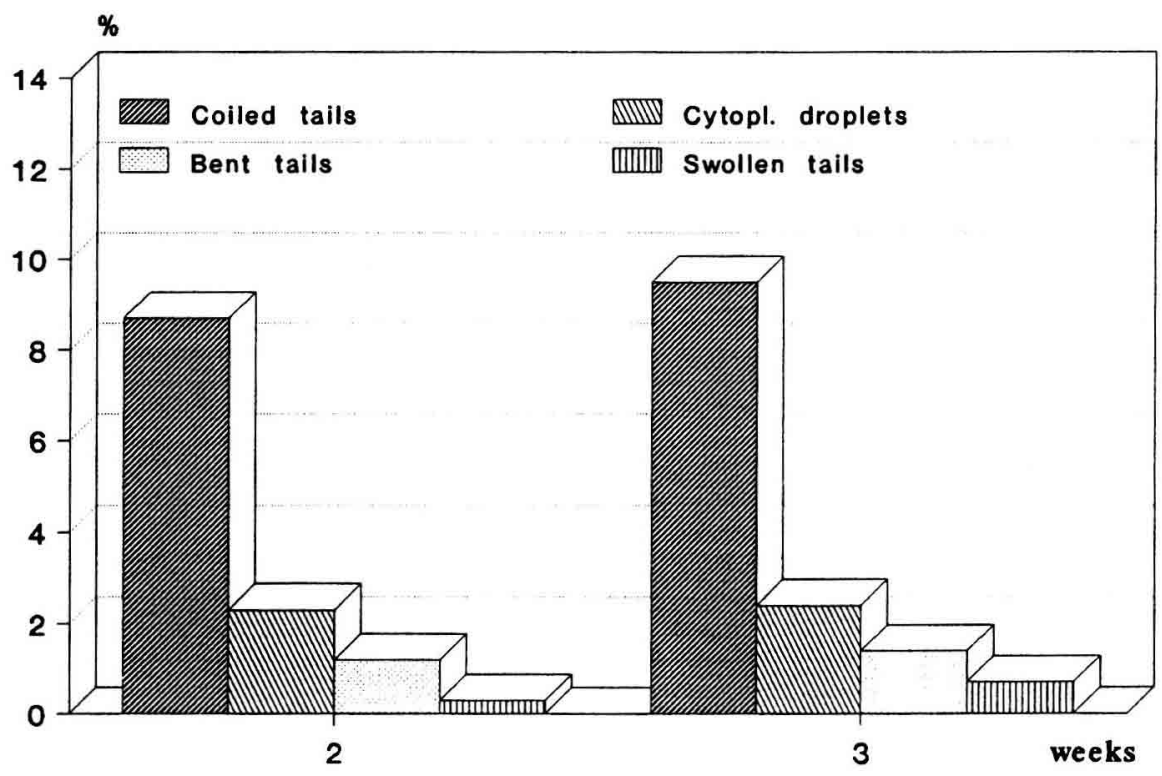

Fig 2. Comparisons between percentages of spermatozoa with different tail abnormalities verified by phase contrast light microscope. 
In figure 3 the large differences between the males tested relative to total sperm abnormalities and, for the same animals, the differences among the data collected in the 3 weeks of experimentation are shown.
Data are analysed in table I where the levels of significance for the different factors considered in the statistical model are reported. The interaction between factors is not indicated because it was found to be insignificant.

Table I. Effect of different sources of variation on different morphological variables considered.

Morphological variables

\section{Subject}

$(1, \ldots 10)$

\section{Week}

$(1, \ldots 3)$
Total abnormalities

Head abnormalities

Tail abnormalities

Broken spermatozoa

Bent tails

Cytoplasmic droplets

Coiled tails

Swollen tails

$\begin{array}{cc}\star \star & \text { ns } \\ \text { ns } & \text { ns } \\ \star & \text { ns } \\ \star & \text { ns } \\ \text { ns } & \text { ns } \\ \star \star & \text { ns } \\ \star & \text { ns } \\ \text { ns } & \star\end{array}$

ns

* Significant effect for $P<0.05$; ${ }^{\star \star}$ Significant effect for $P<0.01$; ns : no significant effect.

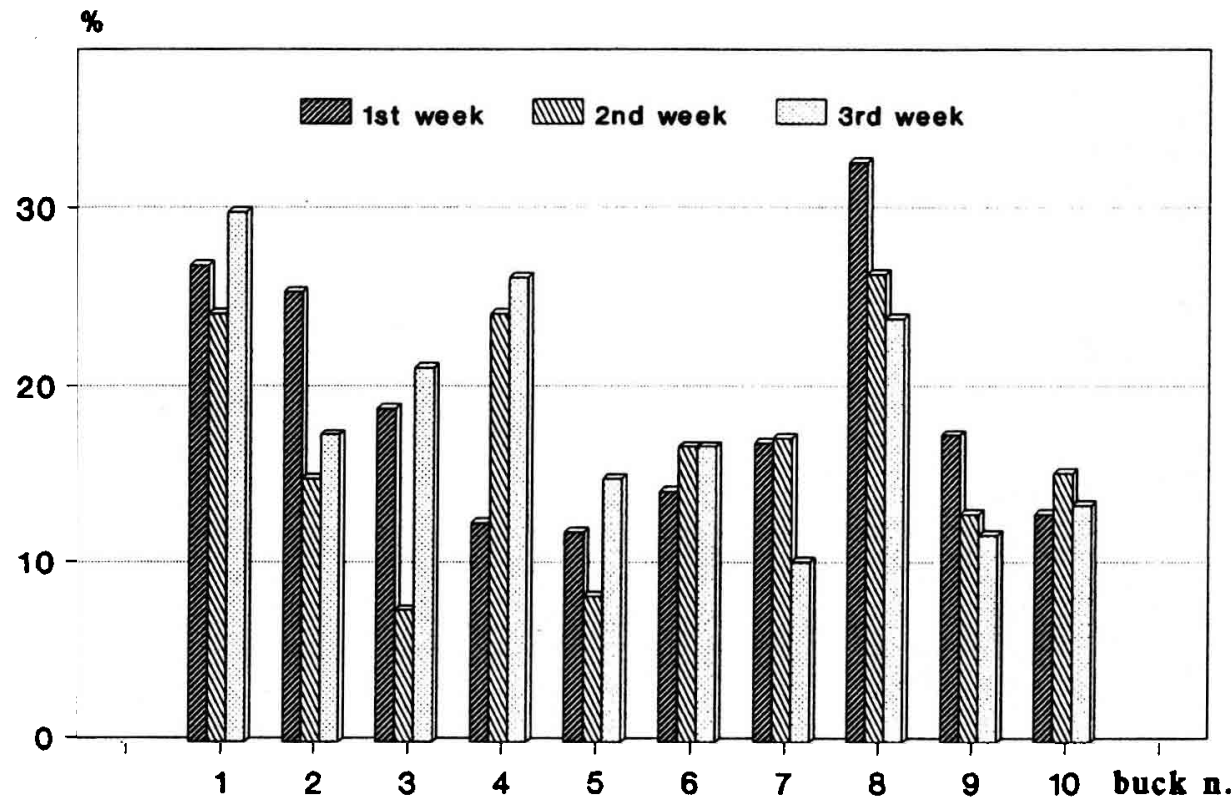

Fig 3. Percentages of total spermatic abnormalities verified by phase contrast light microscope in different bucks in the 3 weeks of observation. 


\section{Qualitative analysis by SEM}

The normal morphology of rabbit spermatozoa is shown in figure 4. SEM analyses of the categories of abnormalities identified by LM permitted a more detailed description of several morphological typologies.

\section{Head morphological abnormalities}

Most major head abnormalities are located in the acrosomal area and were classified into seven typologies:

1) Acrosome bearing several 'bulges'; there were usually two on each side but they were sometimes observed to be supernumerary (three, four or five on each side) (fig 5a);

2) Knobbed acrosome. The margin that externally limits the acrosome, usually horseshoe-shaped, showed one or two small protrusions. The appearance of this abnormality was at an angle to the apex of the acrosome or two lateral angles (fig 5b);
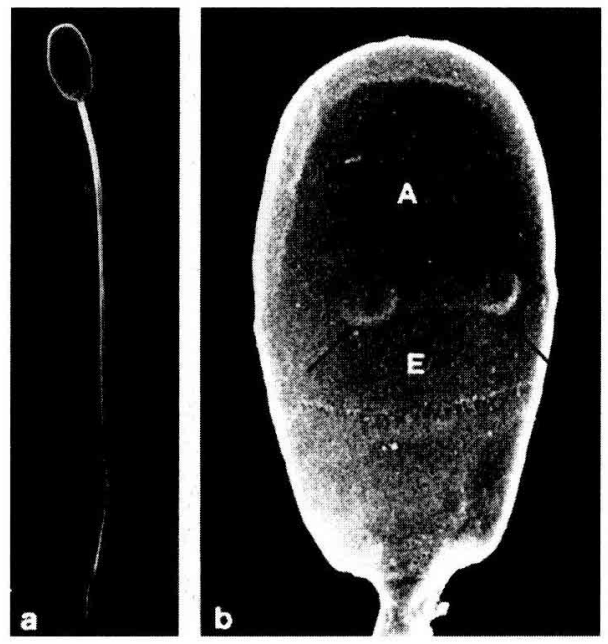

Fig 4. Outline of a normal spermatozoon observed by scanning electron microscope. a: General view (x 2 000); b: particularity of the head with the two characteristic bulges (arrows) (x 15000 ); A: anterior part of the acrosome; E: equatorial segment.
3) Ruffled acrosome. The acrosome appeared turgidless and the plasma membrane seemed wrinkled throughout the acrosomal region (fig $5 \mathrm{c}$ );

4) Retracted acrosome with swollen cords. The acrosomal cap looked retracted from the front because it was detached from its back margin. The entire surface was characterized by swollen cords and irregularly shaped protuberances (fig $5 d$ );

5) Vesiculated acrosome. The outer surface of the front region of the acrosome showed many little contiguous vesicles (fig $5 \mathrm{e}$ );

6) Swollen acrosome. The acrosomal cap looked swollen and its outer surface was irregular; in one case, it was also observed to have a double head (fig 5f);

7) Head lacking an evident acrosome or with a very reduced acrosome (fig 6a). Shape abnormalities of the head were observed, even if fewer in number, in the postacrosomal region as well. The head could appear small, with abnormalities at the level of the terminal ring (fig 6a) or have an aberrant shape (fig $6 \mathrm{~b}$ ).

\section{Tail morphological abnormalities}

At the neck level the observed abnormalities were:

1) Abaxial tail (fig 6b);

2) Swollen tail. A more or less marked swelling, consisting of a very proximal cytoplasmic droplet which formed a sort of collar at the neck region (figs 5d; 6a,c).

The middle piece and principal tail piece showed many abnormalities grouped as follows:

3) Tail with cytoplasmic droplets. Cytoplasmic droplets were observed in a coaxial or lateral position with regard to the axoneme and were found at different sites mainly in the middle piece of the tail (figs $5 e, 7 a, b$ );

4) Tail with a marked anglar deviation of the axoneme. This abnormality was often asso- 

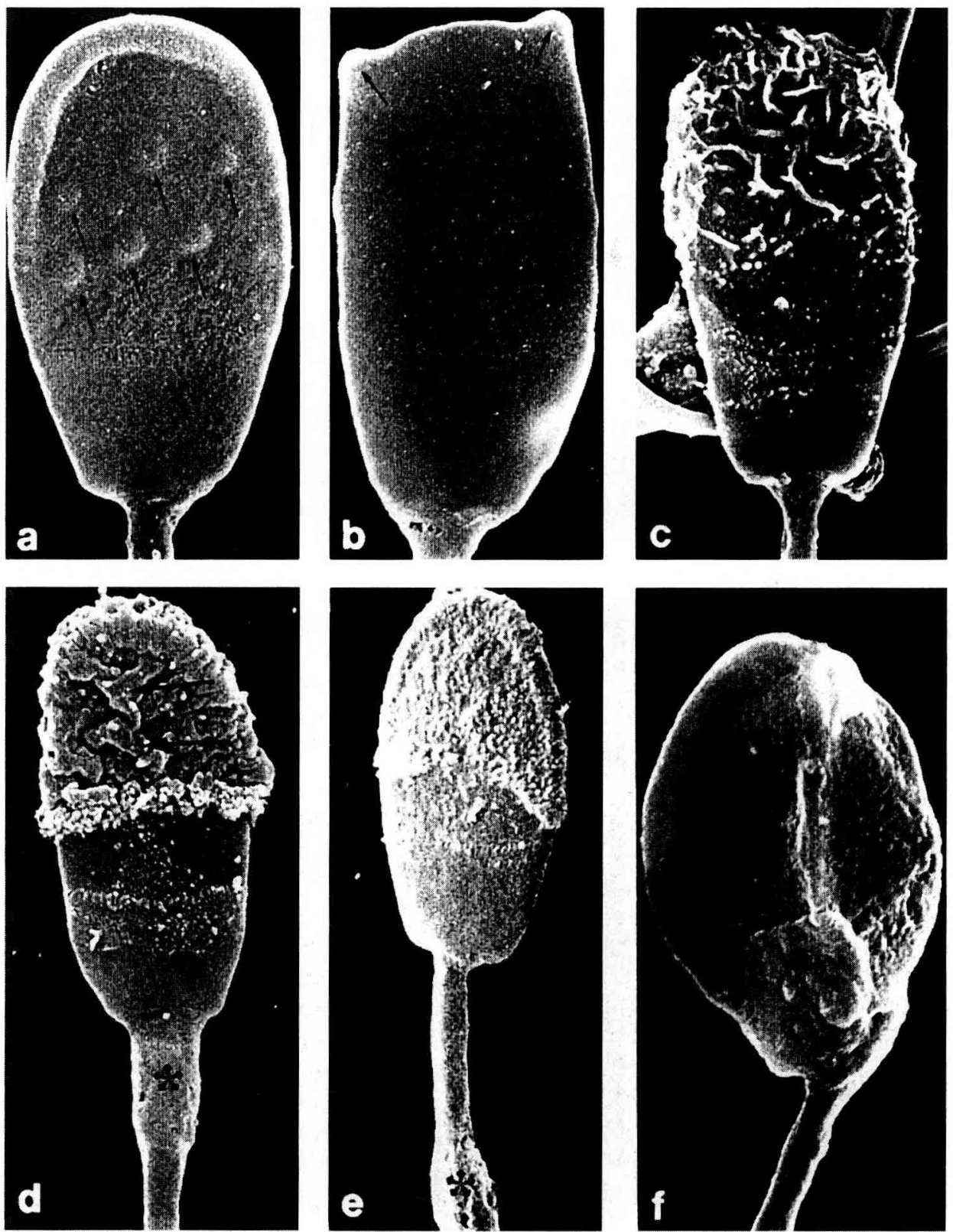

Fig 5. Acrosomal abnormalities observed by scanning electron microscope. a: Acrosome bearing several 'bulges' (arrows) (x 12 000) ; b: knobbed acrosome with two acrosomal protrusions (arrows) (x 12 000); c: ruffled acrosome (x 10000$)$; d: retracted acrosome with swollen cords (arrows) (asterisk: cytoplasmic droplet) (x 9000 ); e: vesiculated acrosome and cytoplasmic droplet in the middle tail (asterisk) (x 8500 ); $f$ : double head ( 8 000). 
ciated with the presence of a cytoplasmic droplet (fig 7a,b);

5) Single and double bent tail. The tail appeared folded one (fig 7c) or more times (fig 7d) and, occasionally, it even wrapped around the head. The loop that was formed by the fold was sometimes occupied by a residue of cytoplasm that gave a characteristic spatula-like shape (fig 7c);

6) Coiled tail. The tail was not angularly deviated and eventually assumed an undulated or spiral conformation; it was sometimes in the shape of a ring (fig 7e);

7) Double tail. It appeared to be made up of two flagella which were either completely joined or diverged from different points (fig $7 f)$.
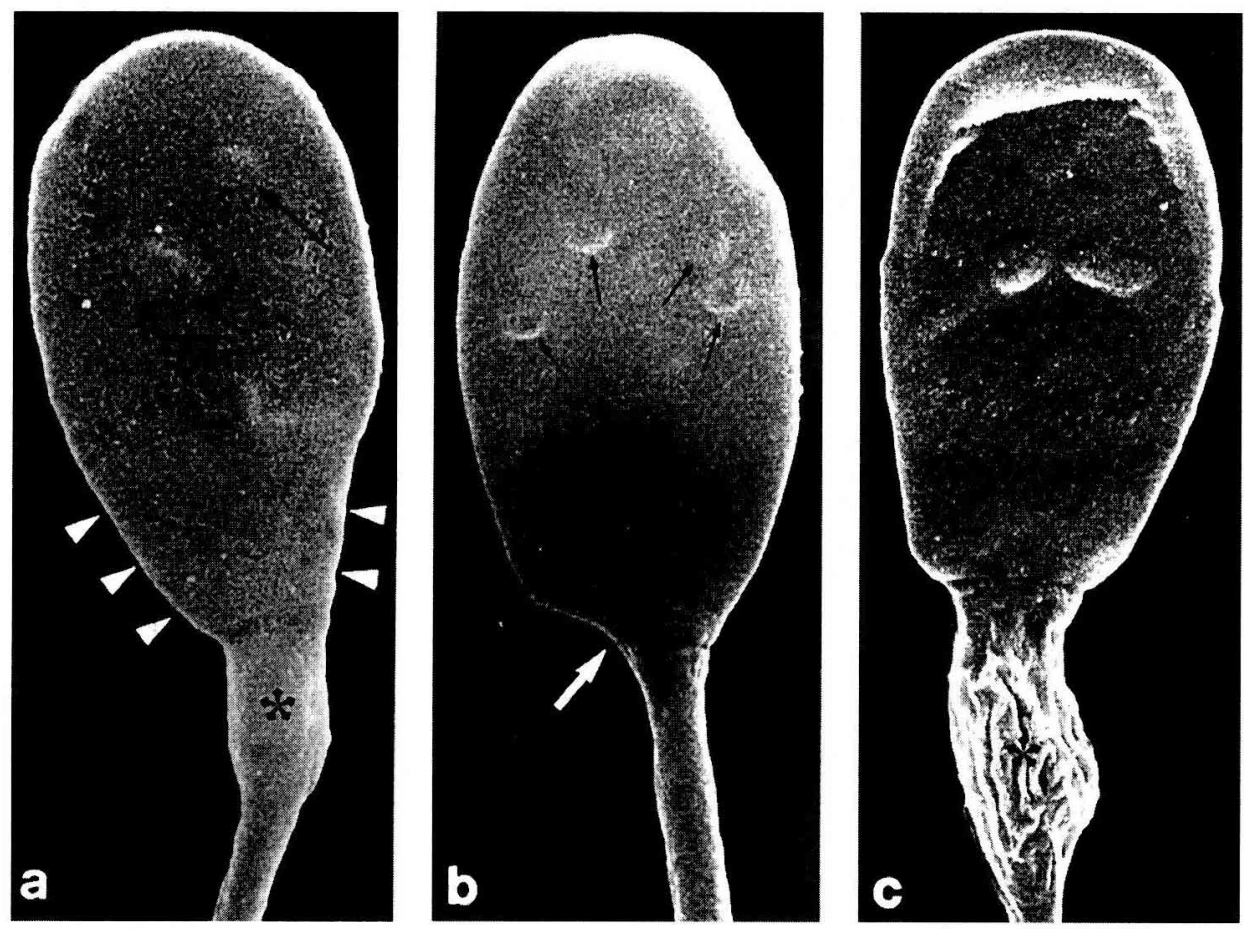

Fig 6. a: postacrosomal region aberrant in shape (arrowheads) and swelling at the neck (asterisk). Note reduced acrosome with two bulges in abnormal position (arrows); $\mathbf{b}$ : reduced acrosome with supernumerary bulges (black arrows) and abaxial tail (white arrow); $\mathbf{c}$ : marked swelling at the neck (asterisk) (observed by scanning electron microscope, $x 10000$ ). 

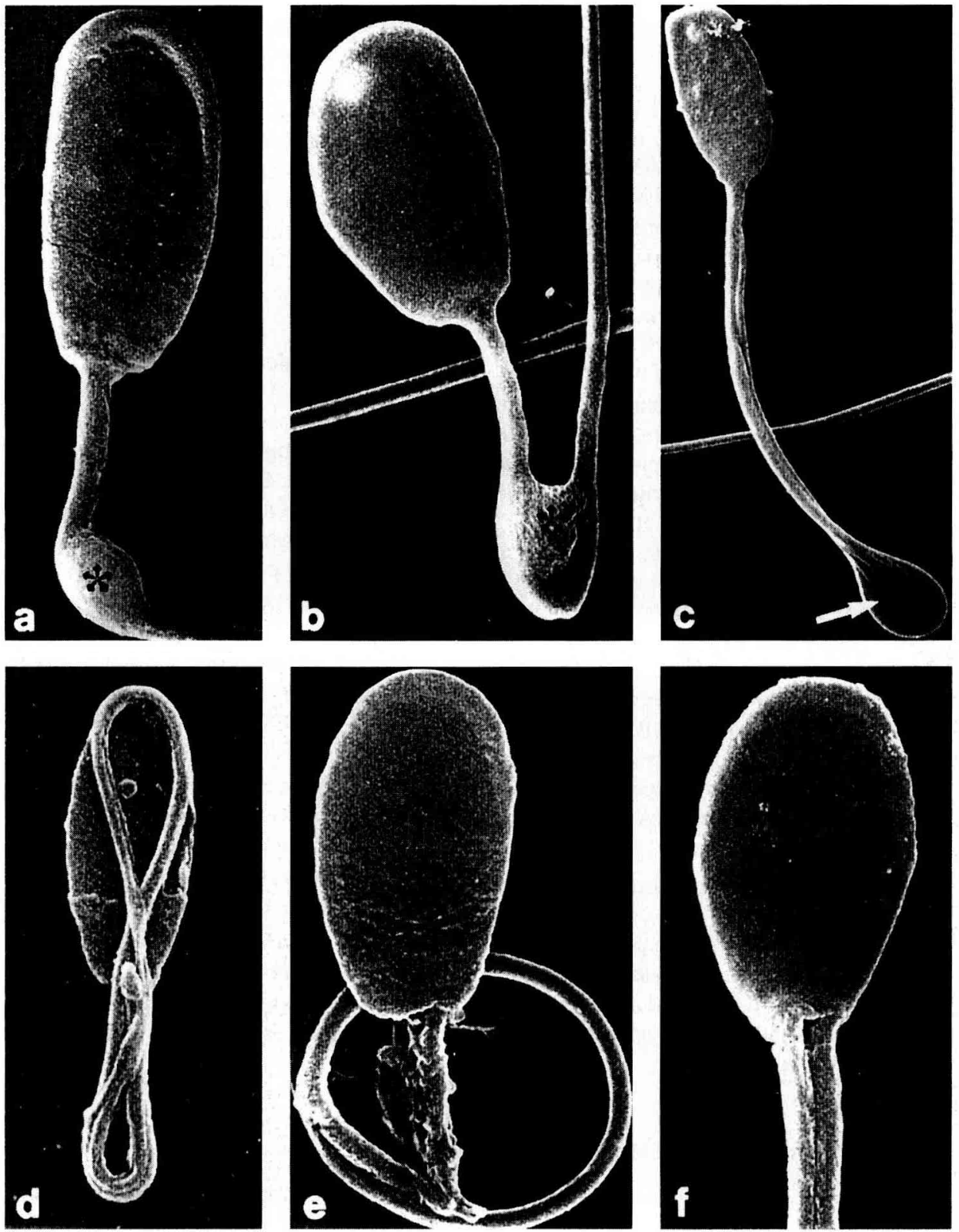

Fig 7. Tail abnormalities observed by scanning electron microscope. a, b: Bent tail with cytoplasmic droplet (asterisks) ( $x 7000$ ); $c$ : single bent tail with a spatula-like loop (arrow) (x 4000$)$; $d$ : double bent tail ( $x 6000)$; e: peculiar coiled tail $(x 8000)$; $f$ : double tail $(x 8000)$. 
Tail abnormalities could be considered as representative of the total abnormality levels as there was a very high correlation between the two parameters $(r=0.97 ; P<$ 0.001 ). This is particularly useful as tail abnormalities are easily observed even at magnifications lower than $x 400$, the level commonly used in practice for semen control for artificial insemination. The observed mean percentage $(13.6 \%)$ obtained in this study was very similar to the values obtained by Radnai et al in $1988(13.0 \%)$ and Roca in $1993(13.6 \%)$. There have been, in fact, very few studies in the literature relative to abnormalities in rabbit spermatozoa, other than tail abnormalities, and the studies that do exist do not agree among themselves (Radnai et al, 1988; Kasa and Thwaites, 1992; Virag et al, 1992; Roca, 1993) or with the results reported here. This is no doubt due to the fact that each study had an independent analysis protocol and different abnormality criterion were considered. Seasonal and genetic differences could be involved as well (Hu et al, 1983; Virag et al, 1992). In addition, magnification levels lower than $x \mathbf{4 0 0}$ could make it impossible to differentiate certain abnormalities (Bagliacca et al, 1987).

Coiled tails, which represented $66.9 \%$ of the total tail abnormalities, could be considered as a representative parameter for verifying individual semen quality $(r=0.91$, $P<0.001$ in relationship to tail abnormalities; $r=0.85, P<0.001$ in relationship to total sperm abnormalities).

\section{Qualitative analysis by SEM}

\section{Head morphological abnormalities}

In the literature, three types of acrosome abnormalities have been observed by LM in some mammalian species; knobbed, ruffled and incomplete acrosome (Saacke, 1970; Barth and Oko, 1989; Ducci et al,
1993). In the present study on rabbits, SEM permits the characterization of further acrosome abnormalities: in particular an acrosome with several bulges, an acrosome that is retracted with swollen cords, and a vesiculated and swollen acrosome. The last two abnormalities were observed by transmission electron microscopy in mammalian spermatozoa (Jones, 1973; Williamson, 1974).

\section{Tail morphological abnormalities}

Most common tail abnormalities have been already described by light microscopy (Saacke, 1970; Barth and Oko, 1989). Observations by transmission electron microscopy of cytoplasmic droplets in the neck, middle or principal piece of the tail have been frequently reported in the literature (Barth and Oko, 1989). This defect is generally intepreted as an index of spermatozoan immaturity because it disappears during the last phase of epididymal maturation (Sorensen, 1979).

The single bent tail is a very common defect (Dott, 1969; Bawa et al, 1993). In bulls this abnormality is very transient in nature, fluctuating throughout the year from low to high levels (Barth and Oko, 1989).

Very few spermatozoa with double tails have been described. Baccetti et al (1978) observed this abnormality in human sperm in relation to hyperprolactinemia disease.

\section{CONCLUSION}

The analysis of spermatozoa abnormalities is important in order to decide on the ejaculates to be used in artificial insemination. The analysis operation could be routine in artificial insemination centres, while under field conditions it would probably only be performed from time to time, mainly to explain low fertility phenomena. 
In order to speed up the analysis process we suggest that only the percentage of coiled tails are counted. These are the most representative of the tail abnormalities and are easily observed under the LM even at low magnification. In order for an ejaculate sample to be considered acceptable, the coiled tail level should not exceed 17-18\% over at least 200 observed spermatozoa.

SEM analysis is not a feasible practical technique for artificial insemination screening; however, when one of the morphological categories identified by LM is prevalent, it could be a useful technique to further analyse the abnormal typology.

\section{ACKNOWLEDGMENTS}

The research was supported by the Italian National Research Council.

\section{REFERENCES}

Baccetti B, Fraioli F, Paolucci S, Selmi G, Spera G, Renieri $T$ (1978) Double spermatozoa in a hyperprolactinemic man. J Submicrosc Cytol 10, 240-260

Bagliacca M, Francesco C, Paci G (1987) Temperatura e performance di conigli maschi riproduttori. Riv Coniglicoltura 24, 61-65

Bamba K, Cran DG (1988) Effect of rapid warming of bull and rabbit semen. J Reprod Ferti/ 82, 501-507

Barth AD, Oko RJ (1989) Abnormal Morphology of Bovine Spermatozoa. Iowa State University Press, Ames, IO, USA

Battaglini M (1992) Fecondazione artificiale, attenti al maschio. Riv Coniglicoltura 29, 47-51

Bawa SR, Pabst MA, Werner G, Bains HK (1993) Capacitated and acrosoma reacted spermatozoa of goat (Capra indicus): a fluorescent and electron microscopic study. Andrologia 25, 123-135

Boussit B (1989) Reproduction et insemination artificielle en cuniculture. Ed Ass Fr de Cuniculture, Lempdes, France

Castellini C (1993) Produzione di seme e congelamento dello stesso. Corso CEE-TUCEP "Valutazione computerizzata del seme di coniglio in vista della crioconservazione", 13-28
Della Porta P, Della Porta D, Maccario P, Borrelli A (1991) Inseminazione artificiale nel coniglio. Ed Gruppo Azeta, Avellino, Italy

Dott HM (1969) Preliminary examination of bull, ram and rabbit spermatozoa with the stereoscan electron microscope. J Reprod Fertil 18, 133-134

Ducci M, Gazzano A, Sighieri C, Rossi P, Frateschi TL, Martelli F (1993) Valutazione morfologica degli spermatozoi di coniglio. Ann Fac Med Vet Pisa 46, 227237

Facchin E, Castellini C, Cappiotti P (1993) Dispensa di Coniglicoltura. Ed Lapival, Ist Zooprof Sper Venezie, Padova, Italy

Fléchon JE, Bustos-Obregon E (1974) Scanning electron microscope study of rabbit spermatozoa. Andrologia 6, 169-180

Hafez ESE, Kanagawa H (1973) Scanning electron microscopy of human, monkey, and rabbit spermatozoa. Fertil Steril 24, 776-787

Hu JF, Hong ZY, Leng HR, Wang QX (1983) Semen quality of German and Chinese Angora rabbits in summer and autumn. Fur Anim Farming 1, 13-15

Jones RC (1973) Changes occurring in the head of boar spermatozoa: vesiculation or vacuolation of the acrosome? J Reprod Fertil 33, 113-118

Karnovsky MJ (1965) A formaldehyde-glutaraldehyde fixative of high osmolality for use in electron microscopy. J Cell Biol 27, 137A-138A

Kasa IW, Thwaites CJ (1992) Semen quality in bucks exposed to $34^{\circ} \mathrm{C}$ for 8 hours or either 1 or 5 days. $\checkmark$ Appl Rabbit Res 15, 560-568

Motta P, Van Blerkom J (1975) A scanning electron microscopic study of rabbit spermatozoa in the female reproductive tract following coitus. Cell Tissue Res 163, 29-44

Philips DM (1972) Substructure of the mammalian acrosome. J Ultrastruct Res 38, 591-604

Radnai I, Tóth IZ, Bán B (1988) Investigations on semen abnormalities of angora rabbit. IV Congress of WRSA, Budapest, Hungary, 2, 465-471

Roca T (1993) Inseminación artificial en cunicultura. Atti Congr Int de Cunicultura Extrona, 113-128

Saacke RG (1970) Morphology of the sperm and its relationship to fertility. Proceedings III Techn Conf Anim Reprod: Art Ins Nat Assoc Breeding, Chicago, IL, USA, 17-30

Sorensen AM Jr (1979) Animal Reproduction. Principles and Practices. McGraw-Hill, New York, NY, USA

Virag G, Mézes M, Bersényi A (1992) Effect of independent factors on semen characteristics in rabbits. J Appl Rabbit Res 15, 499-504

Williamson $P$ (1974) The fine structure of ejaculated ram spermatozoa following scrotal heating. $J$ Feprod Fertil 40, 191-195 